\title{
ZIC4 wt Allele
}

National Cancer Institute

\section{Source}

National Cancer Institute. ZIC4 wt Allele. NCI Thesaurus. Code C75547.

Human ZIC4 wild-type allele is located 3q24 and is approximately $21 \mathrm{~kb}$ in length. This allele, which encodes zinc finger protein ZIC 4, may play roles in regulation of transcription and development of the cerebellum. Mutations in this gene are associated with Dandy-Walker malformation. 